\title{
PENENTUAN KANDUNGAN LEMAK DAN KOMPOSISI ASAM-ASAM LEMAK PADA BAGIAN BADAN IKAN GABUS (Channa striata) BUDIDAYA DAN LIAR
}

\author{
Alvy M. Umage ${ }^{1 *}$, Julius Pontoh ${ }^{1}$ dan Lidya I. Momuat ${ }^{1}$ \\ ${ }^{1}$ Jurusan Kimia Fakultas Matematika dan Ilmu Pengetahuan Alam Universitas Sam Ratulangi, \\ Jl. Kampus Unsrat, Kleak, Manado 95115 Sulawesi Utara
}

\begin{abstract}
ABSTRAK
Telah dilakukan penentuan kandungan lemak dan komposisi asam-asam lemak pada bagian badan ikan gabus (Channa striata) budidaya dan liar. Penelitian ini bertujuan untuk mengetahui berapa kandungan lemak dan komposisi asam lemak pada bagian badan ikan gabus (Channa striata) budidaya dan liar. Kandungan lemak dilakukan menggunakan metode ektraksi dan diperoleh kandungan lemak bagian badan ikan gabus budidaya $0,07 \%$ dan ikan gabus liar 0,01\%. Lemak ikan diderivatisasi dan dianalisis menggunakan kromatografi gas dan diperoleh komposisi asam lemak tertinggi pada bagian badan ikan gabus budidaya adalah asam lemak oleat $37,1 \%$ diikuti dan diikuti oleh asam lemak palmitat $25,6 \%$ sedangkan asam lemak tertinggi pada bagian badan ikan gabus liar adalah asam lemak palmitat $28,6 \%$ dan diikuti asam lemak oleat $16,9 \%$. Kandungan asam lemak omega-3 pada bagian badan ikan gabus budidaya $5,6 \%$ dan ikan gabus liar $9,0 \%$.
\end{abstract}

Kata kunci: Asam lemak, ikan gabus budidaya dan liar, kromatografi gas

\begin{abstract}
Determination of fat content and composition of fatty acids in the body of snakehead (Channa striata) from cultivated and wild sources. This study aims to determine how much fat content and composition fatty acids in the body of snakehead (Channa striata) from cultivated and wild sources. The fat content were carried out using the extraction method. The fat content of cultured snakehead body was $0.07 \%$ and that of wild fish was $0.01 \%$. Fish fats were derivatized and analyzed using gas chromatography and the highest fatty acid composition on the body of cultivated snakehead fish is $37.1 \%$ oleic fatty acids followed by $25.6 \%$ palmitic fatty acids while the highest fatty acid in the body of a wild snakehead fish is $28.6 \%$ palmitic fatty acid and followed by $16.9 \%$ oleic fatty acid. The content of omega- 3 fatty acids in the body of cultivated snakehead fish is $5.6 \%$ and $9.0 \%$ on wild snakehead fish.
\end{abstract}

Keywords: Fatty acids, wild and cultivated snakehead fish, gas chromatography

\section{PENDAHULUAN}

Kepulauan Indonesia merupakan daerah kontinental dengan perairan campuran arus dari Samudera Indonesia dan Samudera Pasifik dan memiliki perairan darat yang luas, kaya akan sumber-sumber perikanan (Buckle dkk., 2010). Ikan merupakan sumber protein, lemak, vitamin dan mineral yang sangat baik (Panagan, 2011). Ikan gabus atau Channa striata merupakan salah satu ikan air tawar yang banyak disukai oleh masyrakat Indonesia (Asfar dkk., 2014).

Manfaat ikan gabus yang utama adalah sebagai makanan. Namun demikian daging ikan gabus digunakan juga sebagai makanan fungsional dan bahan baku farmasi. Daging ikan ini diketahui mempunyai kasiat biologis bagi tubuh manusia. Hasil penelitian menunjukan bahwa daging ikan gabus mengandung albumin yang mampu mengobati penyakit hati, penyembuhan luka dalam tubuh, antimikroba, pengobatan arthritis, antikanker, antioksidan dan antidepresi (Haniffa dkk., 2014).

Lemak adalah ester asam lemak dari gliserol dan tersimpan sebagai energi dalam tubuh hewan. Lemak digunakan untuk kebutuhan energi jangka panjang, juga untuk pergerakan atau cadangan energi selama periode kekurangan makanan. Dalam tubuh, lemak menyediakan energi dua kali lebih besar dibandingkan protein (Sargent dkk., 2002). Chasanah dkk. (2015) melaporkan bahwa kandungan lemak ikan gabus tergantung pada lingkungan tumbuh ikan. Di lingkungan liar, kandungan lemaknya $0,4 \%$ dan di lingkungan budidaya adalah $2,7 \%$.

Komposisi asam lemak dalam minyak ikan gabus kebanyakan mengandung asam lemak jenuh (Saturated Fatty Acid/SFA) yang lebih tinggi, jika

\footnotetext{
* Korespondensi:

Telepon: +62 852-5605-5130

Email: alvianchem15try@gmail.com

DOI: https://doi.org/10.35799/cp.12.1.2019.27301
} 
dibandingkan asam lemak tak jenuh. Asam lemak tak jenuh terdiri dari Monounsaturated Fatty Acid (MUFA) dan Polyunsaturated Fatty Acid (PUFA) (Pontoh, 2019). Menurut Prahesty dkk. (2017), komposisi asam lemak jenuh yang paling tinggi pada minyak ikan gabus adalah asam heksadekanoat (asam palmitat).

Ikan juga mengandung asam lemak, terutama asam lemak omega-3 yang sangat penting bagi kesehatan dan perkembangan otak manusia untuk potensi kecerdasannya (Panagan, 2011). Menurut Pontoh (2019), ikan gabus kaya akan omega-3. Penelitiannya difokuskan pada ekstraksi minyak di berbagai bagian tubuh ikan gabus. Hasilnya, total kandungan minyak untuk ikan segar utuh adalah $0,41 \%$. Kandungan minyak tertinggi berada di bagian kepala $(63,8 \%)$ diikuti oleh jeroan $(19,9 \%)$ dan perut $(16,3 \%)$. Asam palmitat dan docosahexanoic acid (DHA) adalah asam lemak utama dalam minyak ikan gabus. Minyak ikan gabus mengandung docosahexanoic acid (DHA) dan ecosapentaenoic acid (EPA) berturut-turut sebesar $14,99 \%$ dan $8,65 \%$. DHA dan EPA merupakan asam lemak omega-3.

Penentuan asam lemak dalam minyak ditentukan terlebih dahulu dengan mengubah lemak dalam minyak yang pada umumnya ada dalam bentuk triasilgliserol atau trigliserida menjadi metil ester asam lemak dengan metode derivatisasi (Ackman, 1982). Metode derivatisasi merupakan proses kimiawi untuk mengubah suatu senyawa menjadi senyawa lain yang mempunyai sifat-sifat yang sesuai untuk dilakukan analisis menggunakan kromatografi gas (Gandjar dkk., 2012). Keunggulan penggunaan metode kromatografi gas dapat mendeteksi sampai pada jumlah nanogram, resolusi tinggi dan jumlah sampel yang di butuhkan sedikit (Gritter, 1991). Penelitian ini bertujuan untuk mengetahui kandungan lemak dan komposisi asam-asam lemak pada bagian badan ikan gabus (Channa straiata) budidaya dan liar.

\section{BAHAN DAN METODE}

\section{Alat dan bahan}

Alat-alat yang telah digunakan yaitu, pisau, talenan, kompor gas, panci stainless steel, botol transparan $600 \mathrm{~mL}$, kaca arloji, pipet tetes, tabung reaksi, sentrifuge, botol vial, corong pisah, timbangan analitik, aluminium foil, tisu, seperangkat alat kromatografi gas Shimadzu (GC2014), pipet volumetrik, labu takar, dan gelas ukur. Bahan-bahan yang telah digunakan yaitu, sampel ikan gabus yang dibudidaya dan liar, yang diperoleh dari kolam ikan dan pasar Tondano. Untuk bahan kimia yang digunakan yaitu metanol, $\mathrm{NaOH}$, aquades, heksana, asam asetat glasial dan Supelco 37 Component FAME Mix (standar).

\section{Ekstraksi dan penetapan kadar lemak}

Prosedur ekstraksi dan penetapan kadar lemak menurut Pontoh (2018). Ikan dibersihkan dari sisiknya kemudian dipotong bagian tubuh untuk memisahkan badan. Selanjutnya bagian badan tersebut diblender. Sampel yang sudah diblender dipindahkan ke panci stainless steel dan ditambahkan air 2 kali volume sampel. Sampel direbus selama sekitar 1 jam pada suhu $100^{\circ} \mathrm{C}$ dan ditambahkan air untuk menjaga volume air konstan. Selanjutnya sampel dibiarkan dingin, diambil dan dimasukkan ke dalam botol transparan $600 \mathrm{~mL}$ dengan leher sempit panjang. Setelah kaldu berada di dalam botol, fraksi lemak menumpuk di bagian atas kaldu. Lemak disalurkan ke tabung sentrifuge kemudian disentrifugasi selama 15 menit pada 1000 rpm. Lemak dipisahkan dan dikumpulkan untuk analisis lebih lanjut. Kandungan lemak dihitung sebagai berat lemak dibagi dengan berat sampel dikali100\%. Kadar lemak dapat dihitung dengan rumus:

$$
\% \text { Total lemak }=\frac{\text { berat lemak }}{\text { berat sampel }} \times 100 \%
$$

\section{Penetapan kadar air}

Sebanyak 3 g sampel (daging ikan gabus dibudidaya dan liar) dimasukkan ke dalam oven pada suhu $105{ }^{\circ} \mathrm{C}$ selama 3 jam, kemudian dikeluarkan dari oven dan didinginkan dalam desikator selama 30 menit, setelah itu sampel ditimbang. Perlakuan ini dilakukan beberapa kali hingga berat sampel konstan. Kadar air dihitung berdasarkan rumus:

$$
\frac{(\mathrm{A}+\mathrm{C})-\mathrm{B}}{\mathrm{C}} \times 100 \%
$$

Keterangan: $\mathrm{A}=$ berat cawan $(\mathrm{g}), \mathrm{B}=$ berat awal $(\mathrm{g}), \mathrm{C}$ $=$ berat akhir $(\mathrm{g})$

\section{Analisis asam lemak}

\section{Derivatisasi}

Sampel $50 \mathrm{mg}$ dilarutkan dalam $1 \mathrm{~mL}$ heksana kemudian ditambahkan $2 \mathrm{~mL} 0,5 \mathrm{M}$ $\mathrm{NaOH}$ dalam metanol selanjutnya dipanaskan selama 10 menit pada suhu $50{ }^{\circ} \mathrm{C}$ setelah itu didinginkan dan ditambahkan $0,1 \mathrm{~mL}$ asam asetat glasial dan $5 \mathrm{~mL}$ aquades. Larutan sampel didiamkan selama beberapa menit dan terbentuk 2 lapisan, lapisan atas dan lapisan bawah. Lapisan 
atas diambil $1 \mathrm{~mL}$ lalu dimasukkan ke dalam botol vial, kemudian lapisan bawah diekstrak lagi dengan heksana sebanyak 2 x $5 \mathrm{~mL}$. Ketiga hasil filtrat tersebut disatukan dengan perbandingan 1:1:1 (v/v). Dari botol vial tersebut diambil sebanyak $1 \mu \mathrm{L}$ untuk dianalisis di kromatografi gas (Christie, 1989).

\section{Analisis kromatografi gas (Pontoh, 2016)}

Analisis kromatografi dilakukan menggunakan Shimadzu Gas Chromatography (GC-2014) dengan Flame Ionization Detector (FID) dan kolum Thermo Scientific (TR-FAME) dengan panjang $30 \mathrm{~m}$, diameter $0.25 \mathrm{~mm}$, ketebalan film $0.25 \mu \mathrm{m}$. Suhu kolom dari $120^{\circ} \mathrm{C}$ selama 7 menit lalu meningkat secara bertahap sampai $240{ }^{\circ} \mathrm{C}$ dengan peningkatan suhu 10 ${ }^{\circ} \mathrm{C} /$ menit dan dipertahankan selama 5 menit pada suhu konstan sebesar $250{ }^{\circ} \mathrm{C}$. Suhu injeksi dipanaskan pada $260{ }^{\circ} \mathrm{C}$, dilengkapi dengan injector split-pisah dengan $1 / 10$ dan tekanan gas pembawa helium diatur pada $75 \mathrm{kPa}$. Suhu detector adalah $270{ }^{\circ} \mathrm{C}$. Satu mikroliter sampel dimasukkan ke tempat injeksi.

\section{Penentuan kandungan asam lemak}

Waktu retensi asam-asam lemak minyak ikan ditentukan berdasarkan waktu retensi asamasam lemak Supelco 37 component FAME mix (Khan, 2013). Komposisi asam-asam lemak dalam minyak ikan ditentukan berdasarkan jumlah luas puncak metil ester asam-asam lemak dibagi total luas puncak dikali $100 \%$. Rumus persen luas puncak:

$\frac{\text { Luas puncak metil ester asam lemak }}{\text { Total luas puncak metil ester asam lemak }} \times 100 \%$

\section{HASIL DAN PEMBAHASAN}

\section{Kadar air dan kadar lemak}

Pengujian kadar air dilakukan untuk mengetahui banyaknya kadar air dari sampel. Berdasarkan Tabel 1, kadar air yang tertinggi terdapat pada ikan gabus liar dengan nilai kadar air (79,02\%) sedangkan ikan gabus budidaya memiliki nilai kadar air terendah yaitu $(77,77 \%)$.
Hal ini juga sama dengan hasil penelitian yang dilaporkan Chasanah dkk., (2015), yang menyatakan kadar air ikan gabus liar memiliki nilai kadar air yang lebih tinggi dibandingkan nilai kadar air pada ikan gabus budidaya. Menurut Murray dkk. (2009), bahwa pada dasarnya komposisi ikan sebagian besar mengandung air yang kadarnya sebanyak (65-80\%). Hal ini disebabkan karena kadar air pada ikan sangat bervariasi, baik antar jenis yang satu dengan yang lain, antara individu dalam jenis dan bahkan antar bagian-bagian tubuh dalam satu individu (Syarief, 1989).

Tabel 1. Kadar air dan kadar lemak

\begin{tabular}{lcc}
\hline Kadar & $\begin{array}{l}\text { Ikan gabus } \\
\text { budidaya }\end{array}$ & $\begin{array}{l}\text { Ikan gabus } \\
\text { liar }\end{array}$ \\
\hline Air & $77.77 \%$ & $79.02 \%$ \\
Lemak & $0.07 \%$ & $0.01 \%$ \\
\hline
\end{tabular}

Kadar lemak dilakukan untuk mengetahui banyaknya lemak pada bagian badan ikan gabus budidaya dan liar. Berdasarkan pada Tabel 1, kandungan kadar lemak tertinggi terdapat pada ikan gabus budidaya $0,07 \%$ jika dibandingkan dengan ikan gabus liar 0,01\%. Chasanah dkk. (2015), melaporkan bahwa kandungan lemak ikan gabus tergantung pada lingkungan tumbuh ikan, dimana kandungan lemak tertinggi terdapat pada ikan gabus budidaya sedangkan ikan gabus yang liar memiliki kandungan lemak terendah. Faktor utama perbedaan kadar lemak ikan dapat dipengaruhi oleh jenis ikan, kebiasaan makan, kedewasaan, musim dan ketersediaan pakan (Nianda, 2008).

\section{Penentuan asam-asam lemak}

Penentuan asam-asam lemak dalam lemak ikan ditentukan berdasarkan waktu retensi asamasam lemak Supelco 37 Component FAME Mix sebagai standar yang terdapat pada Gambar 1 . 


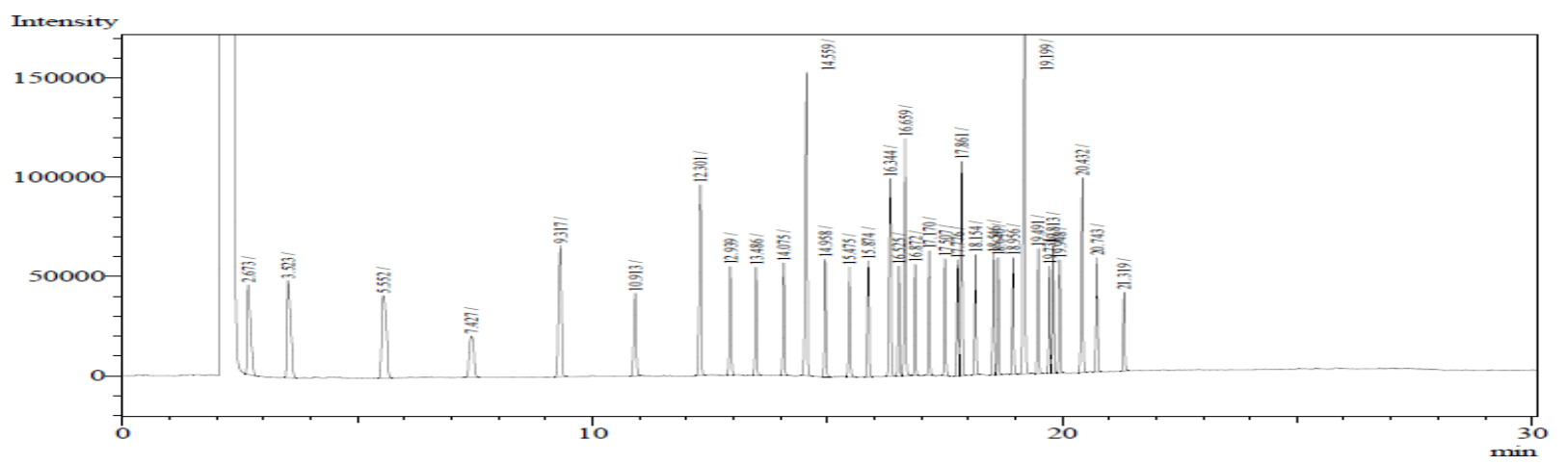

Gambar 1. Kromatogram larutan standar FAME

FAME (Fatty Acid Methyl Ester) maupun kuantitatif (Cropper \& Heywood, 1953). merupakan senyawa turunan dari asam lemak Asam-asam lemak yang terkandung dalam ikan yang memiliki gugus fungsi ester. Pada analisis terdiri atas asam lemak jenuh (15-25\%), asam sampel biasanya senyawa ini digunakan sebagai lemak tak jenuh tunggal (35-60\%) dan asam lemak bahan baku atau standar untuk analisis kualitatif tak jenuh majemuk (24-40\%) (Berge dkk., 2005).

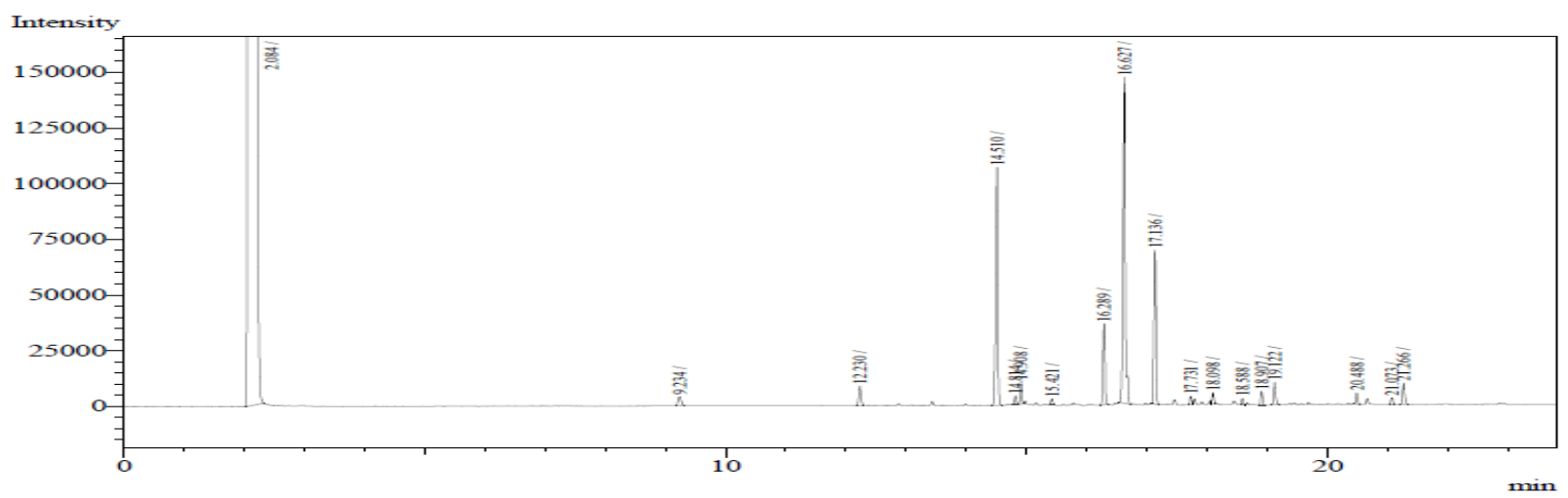

Gambar 2. Kromatogram ikan gabus budidaya

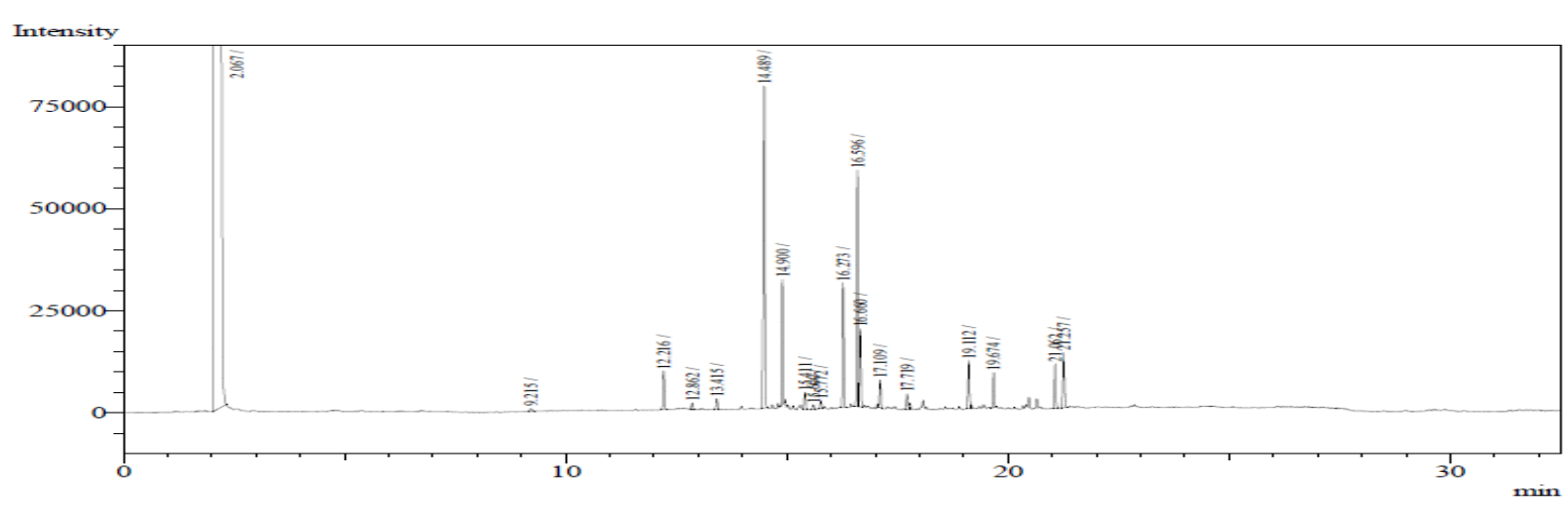

Gambar 3. Kromatogram ikan gabus liar

Pada Gambar 2 dan 3, Komposisi asam lemak yang terdapat pada ikan gabus budidaya dan liar yang teridentifikasi beradasarkan standar FAME yaitu masing-masing 21 jenis asam lemak dan 18 jenis asam lemak. Kandungan asam lemak tertinggi ikan gabus budidaya yang terdapat pada gambar 2 adalah asam lemak oleat diikuti dengan asam lemak palmitat dan asam lemak linoleat. Sedangkan untuk kandungan asam lemak tertinggi ikan gabus liar yang terdapat pada gambar 3 adalah asam lemak palmitat dan diikuti dengan asam lemak oleat dan palmitoleat. Perbedaan asam lemak ikan disebabkan kerana makanan dan lingkungan ikan yang berbeda.

\section{Analisis profil asam lemak}

Analisis profil asam lemak yang terdapat pada asam lemak jenuh dan asam lemak tak jenuh pada ikan gabus budidaya dan ikan gabus liar dapat dilihat pada Tabel 2. 
Tabel 2. Komposisi asam-asam lemak yang terkandung dalam ikan gabus budidaya dan liar

\begin{tabular}{|c|c|c|}
\hline Asam Lemak & Gabus budidaya (\%w/w) & Gabus liar (\%w/w) \\
\hline C-12 (Laurat) & $1.8 \pm 0.5$ & $0.3 \pm 0.1$ \\
\hline C-14 (Miristat) & $2.3 \pm 0.2$ & $3.3 \pm 0.7$ \\
\hline C-15 (Pentadekanoat) & $0.2 \pm 0.3$ & $1.2 \pm 0.3$ \\
\hline C-16 (Palmitat) & $25.6 \pm 0.1$ & $28.6 \pm 0.5$ \\
\hline C-17 (Heptadekanoat) & $0.6 \pm 0.1$ & $1.8 \pm 0.6$ \\
\hline C-18 (Stearat) & $7.3 \pm 0.7$ & $9.8 \pm 0.9$ \\
\hline C-20 (Arakidat) & $0.2 \pm 0.3$ & - \\
\hline C-21 (Heneikosanoat) & $0.5 \pm 0.0$ & - \\
\hline C-22 (Behenat) & $1.1 \pm 0.2$ & - \\
\hline \multicolumn{3}{|l|}{ C-23 (Trikosilat) } \\
\hline Total SFA & 39.5 & 45 \\
\hline C-14:1 (Miristoleinat) & - & $0.7 \pm 0.1$ \\
\hline C-16:1 (Palmitoleat) & $2.0 \pm 0.0$ & $10.2 \pm 0.2$ \\
\hline C-17:1 (Heptadekanoic) & $0.0 \pm 0.1$ & $0.8 \pm 0.4$ \\
\hline C-18:1 Trans (Elaidat) & - & $10.2 \pm 14.5$ \\
\hline C-18:1 Cis (Oleat) & $37.1 \pm 0.7$ & $16.9 \pm 15.3$ \\
\hline C-20:1 Cis (Eikosenoat) & $0.0 \pm 0.2$ & - \\
\hline C-24:1 (Nervonat) & $0.0 \pm 0.3$ & - \\
\hline Total MUFA & 40 & 38.8 \\
\hline \multicolumn{3}{|l|}{ C-18:2 Trans (Linolelaidic) } \\
\hline C-18:2 Cis (Linoleat) & $14.0 \pm 0.2$ & $3.2 \pm 1.4$ \\
\hline C-18:3 Cis-6 ( $\gamma$-Linolenat) & $0.8 \pm 0.0$ & $2.0 \pm 1.0$ \\
\hline C-18:3 Cis-9 ( $\alpha$-Linolenat) & $0.7 \pm 0.5$ & $0.5 \pm 0.7$ \\
\hline C-20:2 Cis (Eikosadienoat) & $0.1 \pm 0.1$ & - \\
\hline C-20:3 Cis (Eikosatrienoat) & $2.0 \pm 0.2$ & $3.9 \pm 0.6$ \\
\hline C-20:4 (Arakidonat) & - & $2.0 \pm 1.1$ \\
\hline C-20:5 (EPA) & $0.9 \pm 0.2$ & $0.7 \pm 1.0$ \\
\hline C-22:6 (DHA) & $2.0 \pm 0.4$ & $3.9 \pm 2.2$ \\
\hline Total PUFA & 20.4 & 16.1 \\
\hline C-18:3 Cis-9 ( $\alpha$-Linolenat $)$ & $0.7 \pm 0.5$ & $0.5 \pm 0.7$ \\
\hline C-20:3 Cis (Eikosatrienoat) & $2.0 \pm 0.2$ & $3.9 \pm 0.6$ \\
\hline C-20:5 (EPA) & $0.9 \pm 0.2$ & $0.7 \pm 1.0$ \\
\hline C-22:6 (DHA) & $2.0 \pm 0.4$ & $3.9 \pm 2.2$ \\
\hline Total Omega-3 & 5.6 & 9.0 \\
\hline
\end{tabular}

Komposisi asam lemak jenuh (SFA) pada bagian tubuh ikan gabus budidaya dan liar, memiliki perbedaan pada total asam lemak. Pada Tabel 2, kandungan asam lemak jenuh tertinggi ikan gabus liar jika dibandingkan dengan ikan gabus budidaya. Kandungan asam lemak jenuh tertinggi terdapat pada asam lemak palmitat dengan kandungan masing-masing ikan gabus budidaya $25,6 \%$ dan liar 28,6\%. Menurut Pontoh, (2019), asam lemak jenuh utama pada ikan gabus yaitu asam lemak palmitat. Komposisi asam lemak palmitat pada pada ikan gabus bagian pada perut $(29,75)$. 
Komposisi asam lemak tak jenuh (MUFA) juga memiliki perbedaan pada total asam lemaknya. Kandungan asam lemak tak jenuh (MUFA) tertinggi terdapat pada ikan gabus budidaya jika dibandingkan dengan ikan gabus liar. Asam lemak utama ikan gabus budidaya dan liar adalah asam lemak oleat dengan kandungan tertinggi secara berturut-turut $40,0 \%$ dan $38,8 \%$. Sedangkan asam lemak tak jenuh (PUFA), kandungan asam lemak tertinggi terdapat pada ikan gabus budidaya. Asam lemak utama (PUFA) adalah asam lemak linoleat dengan kandungan tertinggi terdapat pada ikan gabus budidaya 14,0\% dan ikan gabus liar 3,2\%. Menurut Estiasih (2009), faktor yang juga mempengaruhi perbedaan kadar asam lemak tak jenuh dalam ikan adalah perkembangan dan pertumbuhan, musim, salinitas dan suhu air.

Omega-3 merupakan salah satu asam lemak tak jenuh yang esensial bagi tubuh dan dibutuhkan terutama bagi penderita kolesterol tinggi. EPA dan DHA merupakan jenis omega-3 yang paling dominan pada minyak ikan (Haris, 2004). Pada Tabel 2, Asam lemak yang paling banyak mengandung omega-3 yang ditentukan oleh total asam lemak. Asam lemak dengan kandungan tertinggi yaitu ikan gabus liar jika dibandingkan dengan ikan gabus budidaya. Ikan gabus liar mengandung omega-3 tertinggi terdapat pada badan 9,0\% sedangkan asam lemak budidaya mengandung omega-3 terendah 5,6\%. Asam lemak yang paling banyak mengandung omega-3 terdapat pada bagian badan. Minyak ikan gabus mengandung docosahexanoic acid (DHA) dan eicosapentaenoic acid (EPA) berturut-turut sebesar $14,99 \%$ dan $8,65 \%$.

\section{KESIMPULAN}

Berdasarkan hasil yang didapatkan dari penelitian ini, maka dapat dambil kesimpulan bahwa kandungan lemak pada bagian badan ikan gabus budidaya $0,07 \%$ dan ikan gabus liar $0,01 \%$. Komposisi asam lemak tertinggi pada ikan gabus budidaya adalah asam lemak oleat $37,1 \%$ dan diikuti oleh asam lemak palmitat $25,6 \%$ sedangkan kandungan asam lemak tertinggi pada ikan gabus liar adalah asam lemak palmitat 28,6\% dan diikuti oleh asam lemak oleat $16,9 \%$. Komposisi asam lemak omega-3 pada bagian tubuh ikan gabus budidaya dan liar adalah asam lemak linolenat, eikosatrienoat, EPA dan DHA. Kandungan tertinggi asam lemak omega-3 adalah ikan gabus liar 9,0\% dan kandungan terendah terdapat pada ikan gabus budidaya $5,6 \%$.

\section{DAFTAR PUSTAKA}

Ackman, R.G. 1982. Fatty acid composition in fish oil. Bandung: Academic Press.

Asfar, M., Tawali, A.B., \& Mahendra, M. 2014. Potensi ikan gabus (Channa striata) sebagai sumber makanan kesehatan. Review. Prosiding Seminar Nasional Teknologi Industri.

Berge, J.G \& Branathan, G. 2005. Fatty acids from lipids of marine organisms: molecular biodiversity, roles as biomarkers, biologically active compounds and economical aspects. Advances in Biochemical Engineering. 96(4), 49-125.

Buckle, K.A., Edwards, R.A., Fleet, G.H., \& Wootton, M. 2007. Ilmu pangan. Diterjemahkan oleh Hari Purnomo dan Adiono. Penerbit. Jakarta: Universitas Indonesia.

Chasanah, E., Nurilmala, M., Purnamasari, A. R., \& Fithriani, D. 2015. Komposisi Kimia, Kadar Albumin dan Bioaktivitas Ekstrak Protein Ikan Gabus. Jurnal Pacsapanen dan Bioteknologi Kelautan dan Perikanan. 10(2), 123-132.

Christie, W.W. 1989. Gas chromatography and lipids: A practical guide. Scotland: The Oily Press.

Cropper, F.R., and Heywood, A. 1953. Analytical separation of the methyl Esters of the C12C22 fatty acids by vapour phase chromatography. Nature. 172(25), 11011102.

Estiasih, T. 2009. Minyak ikan teknologi dan penerapannya untuk pangan dan kesehatan. Yoyakarta: Graha Ilmu.

Gandjar, I. G., \& Rohman, A. 2007. Kimia farmasi analisis. Yogyakarta: Pustaka Pelajar.

Gritter, J.R., James, M., Bobbit., \& Arthur, E. 1991. Pengantar kromatografi. Bandung: ITB.

Haniffa, M.A.K., Sheela P.A.J., Kavitha, K., \& Jais, A.M. 2014. Salutary value of haruan, the striped snakehead Channa striatus - a review. Asian Pacific Journal Tropical Biomedicene. 4(1), 8-15.

Haris, W.S. 2004. Review: fish oil supplementation: evidence for health benefits. Cleveland Clinic Journal of Medicine. 71(3), 208-219.

Khan, I. K. 2013. A GC-FID method for the comparison of acid and base-catalyzed derivatization of fatty acids to fames in 
three edible oil. Thermo Fisher Scientific Runcorn, UK. 1(1), 1-8.

Murray, R.K., Granner D.K. \& Rodwell V.W. 2009. Harper"s Illustrated Biochemistry. New York: Lange Medical Publication.

Nianda, T. 2008. Komposisi protein dan asam amino daging ikan gurami (Osphronemus gouramy) pada berbagai sumur panen. Skripsi. Program Studi Teknologi Hasil Perikanan Fakultas Perikanan dan Ilmu Kelautan Institut Pertanian Bogor.

Panagan, A.T., H. Yohandini. \& J.U. Gultom. 2011. Analisis kualitatif dan kuantitatif asam lemak tak jenuh omega-3 dari minyak ikan patin (Pangasius pangasius) dengan metode kromatografi gas. Jurnal Penelitian Sains. 14(4), 38-42.

Pontoh, J. 2019. Extraction and characterization of fish oil from various parts of snakehead fish (Chana striata). International Journal of ChemTech Research. 12(1): 323-328.
Prahesty, F.D., Maulana, I.T., \& Dasuki, U.A. 2017. Fatty acid content profile fish nilem (Osteochillus hasselti) and fish cork (Channa striata) using spectroscopy gas chromatography mass. Prosiding Farmasi. 3(2), 407-414.

Pontoh, J. \& Tumiwa, D. 2018. Gas chromatographic analysis of fatty acid composition in the freshwater fishes in North Sulawesi. Malaysian Journal of Fundamental and Applied Sciences. 179183.

Pontoh, J. 2016. Gas chromatographic analysis of medium chain fatty acids in coconut oil. Journal of Pure and Applied Chemistry Research. 5(3), 157-161.

Sargent, J.R., Tocher, D.R., Bell, J.G. 2002. The lipids, In: Halver, J.E., Hardy, R.W. (Eds.), Fish nutrition, 3rd edition. Academic Press. San Diego. 181-257.

Syarief. 1989. Teknologi penyimpanan pangan. Penerbit Arcan, Jakarta. 